\title{
ATP: a vasoactive signal in the pericyte-containing microvasculature of the rat retina
}

\author{
Hajime Kawamura ${ }^{\star}$, Tetsuya Sugiyama ${ }^{\star}$, David M. Wu †, Masato Kobayashi ${ }^{\star}$, Shigeki Yamanishi ${ }^{\star}$, \\ Kozo Katsumura ${ }^{\star}$ and Donald G. Puro ${ }^{\star} \dagger \neq$ \\ ${ }^{*}$ Department of Ophthalmology and Visual Sciences, $\uparrow$ Neuroscience Graduate Program and $\ddagger$ Department of Molecular and Integrative Physiology, \\ University of Michigan, Ann Arbor, MI 48105, USA
}

\begin{abstract}
In this study we tested the hypothesis that extracellular ATP regulates the function of the pericytecontaining retinal microvessels. Pericytes, which are more numerous in the retina than in any other tissue, are abluminally located cells that may adjust capillary perfusion by contracting and relaxing. At present, knowledge of the vasoactive molecules that regulate pericyte function is limited. Here, we focused on the actions of extracellular ATP because this nucleotide is a putative glial-to-vascular signal, as well as being a substance released by activated platelets and injured cells. In microvessels freshly isolated from the adult rat retina, we monitored ionic currents via perforated-patch pipettes, measured intracellular calcium levels with the use of fura-2, and visualized microvascular contractions with the aid of time-lapse photography. We found that ATP induced depolarizing changes in the ionic currents, increased calcium levels and caused pericytes to contract. $\mathrm{P} 2 \mathrm{X}_{7}$ receptors and UTP-activated receptors mediated these effects. Consistent with ATP serving as a vasoconstrictor for the pericyte-containing microvasculature of the retina, the microvascular lumen narrowed when an adjacent pericyte contracted. In addition, the sustained activation of $\mathrm{P} 2 \mathrm{X}_{7}$ receptors inhibited cell-to-cell electrotonic transmission within the microvascular networks. Thus, ATP not only affects the contractility of individual pericytes, but also appears to regulate the spatial and temporal dynamics of the vasomotor response.
\end{abstract}

(Received 24 May 2003; accepted after revision 22 July 2003; first published online 22 July 2003)

Corresponding author D. G. Puro: Departments of Ophthalmology and Visual Sciences and Molecular and Integrative Physiology, University of Michigan, 1000 Wall Street, Ann Arbor, MI 48105, USA. Email: dgpuro@umich.edu

The vulnerability of neurons to ischaemia requires that blood flow in the nervous system be tightly coupled to metabolic needs. In the inner portion of the mammalian retina, the coupling of capillary perfusion to local needs must be particularly efficient due to the low density of capillaries (Funk, 1997). Although the sparseness of retinal microvessels minimizes vascular interference with light, it results in a tenuous link between the supply of energy substrates and the needs of neurons. For this reason, the retinal circulation is specialized for responsiveness to local demands (Anderson, 1996) and thus provides a useful system for testing hypotheses concerning the mechanisms by which locally derived signals regulate capillary function.

A premise of our study is that the abluminally located pericytes play a role in regulating the perfusion of retinal capillaries. Consistent with this concept, the retina lacks precapillary sphincters (Pannarale et al. 1996), which in most other tissues regulate capillary blood flow. The absence of these sphincters suggests that local perfusion within the retina is regulated, at least in part, within capillaries and not exclusively at proximal sites in the vascular tree. Likely candidates for regulating capillary perfusion are the contractile pericytes that are located on the abluminal wall of the microvasculature. The contraction and relaxation of these cells is thought to regulate the diameter of capillary lumens (Tilton, 1991; Schonfelder et al. 1998; Sakagami et al. 2001; Li \& Puro, 2002; Puro, 2002; Wu et al. 2003). By this mechanism, the perfusion of a capillary may be controlled. Suggestive of a particularly important role for pericytes in the retina, the density of these cells in retinal microvessels is higher than in any other vascular bed (Shepro \& Morel, 1993).

Although it is uncertain how retinal capillary perfusion is efficiently matched to meet neuronal demand, the positioning of glial processes between neurons and blood vessels suggests that glial cells may play a central role. Also consistent with these cells serving to link the nervous and circulatory systems, glia are responsive to a variety of neurotransmitters (Schwartz, 1993; Biedermann et al. 1995; Li et al. 2001). However, identification of glial-tovascular signals is less well established. Although one candidate is potassium, which effluxes from the glia at sites near blood vessels (Paulson \& Newman, 1987; Higashi et al. 2001), the reportedly low permeability of vascular cells to this cation (Hansen et al. 1977) may limit its vasoregulatory role. In this study, we considered the 
possibility that ATP, which can be released by glial cells (Queiroz et al. 1997; Cotrina et al. 2000; Wang et al. 2000; Newman, 2001, 2003), is a vasoactive molecule in the pericyte-containing microvasculature of the retina.

We report that experiments using patch-clamp recordings, intracellular calcium measurements and time-lapse photography support the hypothesis that extracellular ATP regulates the physiology of retinal pericytes. By activating $\mathrm{P}_{2} \mathrm{X}_{7}$ receptors and UTP-binding receptors, ATP altered the ionic currents, increased calcium levels and induced contractions of pericytes located on microvessels freshly isolated from the rat retina. Adjacent to contracting pericytes, the microvascular lumen constricted. In addition, the sustained activation of $\mathrm{P} 2 \mathrm{X}_{7}$ receptors reversibly inhibited cell-to-cell communication within the microvasculature. Thus, extracellular ATP not only affects individual vascular cells, but also regulates the multicellular functional organization of the microvascular network.

\section{METHODS}

\section{Microvessel isolation}

Microvessels from 6- to 8-week-old rat retinas were freshly isolated using a modified 'tissue-print' method (Sakagami et al. 1999; Wu et al. 2001). Animal use conformed to the guidelines of the Association for Research in Vision and Ophthalmology and the University of Michigan Committee on the Use and Care of Animals. Long-Evans rats (Harlan Sprague-Dawley, Inc., Indianapolis, IN, USA) were killed by exposure to a rising concentration of carbon dioxide, and their retinas were rapidly removed and incubated in $2.5 \mathrm{ml}$ Earle's balanced salt solution (Life Technologies, Grand Island, NY, USA) supplemented with $0.5 \mathrm{~mm}$ EDTA, $20 \mathrm{~mm}$ glucose, $15 \mathrm{U}$ papain (Worthington Biochemicals, Freehold, NJ, USA), and $2 \mathrm{~mm}$ cysteine for $30 \mathrm{~min}$ at $30^{\circ} \mathrm{C}$ whilst bubbled with $95 \%$ oxygen $-5 \%$ carbon dioxide in order to maintain $\mathrm{pH}$ and oxygenation. After transfer to Solution A ( $140 \mathrm{~mm} \mathrm{NaCl}, 3 \mathrm{~mm} \mathrm{KCl}, 1.8 \mathrm{~mm} \mathrm{CaCl}_{2}, 0.8 \mathrm{~mm} \mathrm{MgCl}_{2}, 10 \mathrm{~mm}$ Na-Hepes, $15 \mathrm{~mm}$ mannitol, and $5 \mathrm{~mm}$ glucose at $\mathrm{pH} 7.4$ with osmolarity adjusted to 310 mosmoll $^{-1}$ with water), each retina was then gently sandwiched between two glass coverslips $(15 \mathrm{~mm}$ diameter, Warner Instrument Corp., Hamden, CT, USA). Vessels adhered to the coverslip that was in contact with the vitreal side of the retina. By repeating this tissue print step, several coverslips with adherent microvessels could be obtained from a retina.

\section{Electrophysiology}

A coverslip with microvessels was placed in a recording chamber, which was perfused $\left(\sim 2 \mathrm{ml} \mathrm{min}^{-1}\right)$ with solutions from a gravityfed system using multiple reservoirs. Solution $\mathrm{A}$, with or without the addition of various purinergic agents, was used in most experiments, although in some cases (e.g. Fig. 3) we used a modified solution A in which $\mathrm{MgCl}_{2}$ was absent and only $0.3 \mathrm{mM}$ $\mathrm{CaCl}_{2}$ was present. Vessels were examined at $\times 300$ or $\times 400$ magnification with an inverted microscope equipped with phasecontrast optics. Pericytes were identified by their characteristic 'bump on a log' location on the abluminal wall of microvessels (Kuwabara \& Cogan, 1960; Sakagami et al. 1999).

As detailed previously, the perforated-patch configuration of the patch-clamp technique was used to monitor ionic currents and membrane potentials from pericytes located on microvessels that had been isolated from a retina within $3 \mathrm{~h}$ (Sakagami et al. 1999). Pipettes had resistances of $\sim 5 \mathrm{M} \Omega$ and contained a solution consisting of $50 \mathrm{mM} \mathrm{KCl}, 64 \mathrm{mM} \mathrm{K}_{2} \mathrm{SO}_{4}, 6 \mathrm{mM} \mathrm{MgCl}_{2}, 10 \mathrm{mM}$ potassium Hepes, $240 \mu \mathrm{g} \mathrm{ml}^{-1}$ amphotericin, and $240 \mu \mathrm{g} \mathrm{ml}^{-1}$ nystatin at $\mathrm{pH} 7.4$ with the osmolarity adjusted to $280 \mathrm{mosmoll}^{-1}$. Pipettes were mounted in the holder of a patch-clamp amplifier, which was either a Dagan 3900 (Dagan Corp., Minneapolis, MN, USA) or an Axon 200B (Axon Instruments Inc., Union City, CA, USA), and then sealed to the cell bodies of pericytes. As amphotericin-nystatin perforated the patch, the access resistance to the pericytes studied decreased to less than $20 \mathrm{M} \Omega$ within 5 min.

For the generation of current-voltage $(I-V)$ plots, currents were evoked by protocols that were controlled by pCLAMP 8 software (Axon Instruments) and consisted of either steps of voltage (Figs 1, 6B and 8 ) or a negative-to-positive ramping $\left(66 \mathrm{mV} \mathrm{s}^{-1}\right)$ of voltage (Fig. 10). Currents were filtered at $1 \mathrm{kHz}$ with a four-pole Bessel filter, digitally sampled (50 to $400 \mu$ s intervals for steps and $1 \mathrm{~ms}$ for ramps) using a DigiData 1200B acquisition system (Axon Instruments) and stored by a Pentium class computer equipped with pCLAMP 8 and Origin (Version 6.1, OriginLab, Northampton, MA, USA) software for data analysis and graphics display. For continuous recordings of inward current (e.g. Figs $3 \mathrm{~A}$ and $6 A$ ), pericytes were voltage clamped at $-103 \mathrm{mV}$, and sampling was done in $250 \mathrm{~ms}$ intervals.

The amplitude of the steady-state inward current was measured at $-103 \mathrm{mV}$, which is the equilibrium potential of potassium. The amplitude of the outward current was measured at $0 \mathrm{mV}$, which is near the reversal potential for the non-specific conductance recorded in retinal pericytes (Sakagami et al. 1999). For assessment of the effect of ouabain, current amplitudes at -103 and $0 \mathrm{mV}$ were quantified. The net charge transfer via transient calcium-activated chloride currents was quantified during 17 1-s sampling periods in which the holding potential was $-58 \mathrm{mV}$. As reported previously (Sakagami et al. 1999), we calculated the net charge transfer in coulombs by multiplying the duration of each sampling period by the mean amplitude of the transient inward currents during each sampling period. This amplitude was determined by subtracting the amplitude of pericyte current in the absence of any transient events (i.e. the steady-state current) from the mean current amplitude, which was calculated using pCLAMP software. From the 17 sampling periods, we calculated the average net charge transfer. Unless noted otherwise, the zerocurrent potential was defined as the membrane potential of a sampled pericyte. Adjustment for the calculated liquid junction potential (Barry, 1994) was made after data collection.

In some experiments (e.g. Fig. 8), we simultaneously recorded from two pericytes that were located on a freshly isolated microvessel. The membrane potentials of the two current-clamp cells were monitored as a current step of $-30 \mathrm{pA}$ was applied to one of the sampled pericytes. Electrotonic transmission was quantified by comparing the voltage changes at the two recording sites.

Because there are gap junction pathways within retinal microvessels (Oku et al. 2001; Kawamura et al. 2002), currents detected in a pericyte include not only those generated by the ion channels of the sampled cell, but also currents transmitted electronically from neighbouring vascular cells. Although the space clamp would be more controlled in short, rather than long, microvessels, the frequent occurrence of low membrane potentials and unstable 
recordings in microvessels shorter than $\sim 300 \mu \mathrm{m}$ indicated that cells in short capillary fragments are often damaged. For this reason, we recorded from pericytes in microvessels of $>300 \mu \mathrm{m}$ in length even though the voltage clamp of distantly coupled cells would be less than that of the sampled pericyte. Despite space clamp limitations, we previously found in studies of isolated retinal microvessels that the reversal potentials for conductances generated by potassium, chloride and non-specific cation channels closely matched the calculated equilibrium potentials for these ions (Sakagami et al. 1999; Li \& Puro, 2001; Oku et al. 2001; Wu et al. 2001; Kawamura et al. 2002; Wu et al. 2003). Thus, for identification of ionic conductances, it appears that the voltage within a microvessel can be clamped reasonably well at the sites containing the bulk of the ion channels contributing to the current detected in a sampled pericyte.

\section{Calcium imaging}

Freshly isolated pericytes were loaded with $1 \mu \mathrm{M}$ fura-2 AM (Molecular Probes, Eugene, OR, USA) at $37^{\circ} \mathrm{C}$ for $30 \mathrm{~min}$. Afterwards, the microvessel-containing coverslip was positioned in a $200 \mu \mathrm{l}$ recording chamber, which was perfused $\left(\sim 2 \mathrm{ml} \mathrm{min}^{-1}\right)$ via a gravity-fed system using multiple reservoirs. Initially, to give time for the AM ester to be cleaved, the fura- 2 was washed out with Solution A for at least $30 \mathrm{~min}$. Digital imaging of fura-2 fluorescence was then performed at room temperature using an optical sensor (Sensicam, Cooke Corp., Auburn Hills, MI, USA). The light source was a high intensity mercury lamp coupled to an Optoscan Monochromator (Cairn Research Ltd, Faversham, UK). Axon Imaging Workbench (Axon Instruments) was used to control the imaging equipment and to collect data. Microvessels were observed using a Nikon Eclipse TE300 microscope (Nikon, Toyko) at $\times 400$ using a $\times 40$ oil-immersion objective. Fluorescence was measured from pericyte somas that were positioned like a 'bump on a log' at the edge of the endothelial wall; in this way fluorescence from pericytes, not endothelial cells, was monitored. The fluorescence ratio $\left(F_{340 / 380}\right)$ was converted to intracellular calcium concentration using the equation of Grynkiewicz et al. (1985), as detailed previously (Puro \& Stuenkel, 1995). Autofluorescence, determined in unloaded cells, was not detected in the isolated microvessels.

\section{YO-PRO-1 imaging}

A coverslip with freshly isolated pericytes was positioned in a chamber that was located on the stage of a Nikon Eclipse TE300 microscope equipped with a $\times 40$ oil-immersion objective. For $15 \mathrm{~min}$ the microvessels were exposed at room temperature to solution A supplemented with $5 \mu \mathrm{M}$ YO-PRO-1 (Molecular Probes), which is a propidium di-iodide dye that binds to nucleic acids. Subsequently, the microvessels were exposed to the solution containing YO-PRO-1 with or without the addition of $100 \mu \mathrm{M}$ benzoylbenzoyl-ATP (BzATP). Fluorescence was detected with excitation and emission wavelengths of 475 and $510 \mathrm{~nm}$, respectively. The light source was a high-intensity mercury lamp coupled to an Optoscan Monochromator. At 10 min intervals, a complex of microvessels was photographed at $\times 400$ (Nikon camera, Kodak Elite chrome film, $25 \mathrm{~s}$ exposure time). The photographic negatives were digitized (Photoshop 6.0, Adobe, San Jose, CA, USA), the background autofluorescence subtracted, and the fluorescence per pixel of the microvascular nuclei quantified using NIH image software.

In experiments testing the effect of depolarization, the percentage of fluorescent microvascular cells, which was determined by viewing the microvessels at $\times 400$, was compared in microvessels that were incubated for $60 \mathrm{~min}$ in solution A plus $5 \mu \mathrm{M}$ YO-PRO-1 or solution B $\left(100 \mathrm{~mm} \mathrm{KCl}, 43 \mathrm{~mm} \mathrm{NaCl}, 1.8 \mathrm{mM} \mathrm{CaCl}_{2}, 0.8 \mathrm{~mm}\right.$ $\mathrm{MgCl}_{2}, 10 \mathrm{~mm}$ sodium Hepes, $15 \mathrm{~mm}$ mannitol, and $5 \mathrm{~mm}$ glucose at $\mathrm{pH} 7.4$ with osmolarity adjusted to $310 \mathrm{mosmol}^{-1}$ with water) plus YO-PRO-1.

\section{Immunocytochemistry}

After freshly isolated microvessels were fixed for approximately $18 \mathrm{~h}$ with $4 \%$ paraformaldehyde in phosphate-buffered saline (PBS) at $4{ }^{\circ} \mathrm{C}$, their endogenous peroxidase activity was blocked by exposure to $0.3 \%$ hydrogen peroxide in PBS for $30 \mathrm{~min}$. After a 60 min exposure to $0.5 \%$ Triton X-100, coverslips were exposed to rabbit anti-P2X $(1: 1000$, Sigma $)$ for $16 \mathrm{~h}$ at $4{ }^{\circ} \mathrm{C}$. In controls, no primary antibody was used. Subsequently, the coverslips were incubated with biotin-conjugated goat anti-rabbit IgG (Vector Labs, Burlingame, CA, USA) at $1: 200$ for $1 \mathrm{~h}$, and the avidinbiotin-peroxidase complex (Vector Labs) 1:100 for $30 \mathrm{~min}$ followed by development with diaminobenzidine.

\section{Time-lapse photography}

A glass coverslip with freshly isolated microvessels was positioned in a specially built chamber (volume $=200 \mu \mathrm{l}$ ), which was perfused by a gravity-fed mechanism of reservoirs. Vessels were visualized by differential interference contrast optics at $\times 1000$ magnification with a Nikon Eclipse E800 equipped with a $\times 100$ oil-immersion objective. To document changes in pericyte contractile tone, time-lapse images were recorded at $8 \mathrm{~s}$ intervals using a Nikon DCM1200 digital camera and ImagePro Plus software (Media Cybernetics, Silver Spring, MD, USA). The ImagePro Plus software also facilitated the measurement of lumen diameters in the time-lapse photographs. Because contracting pericytes could cause microvascular lumens to move out of the narrow depth of focus available with differential interference contrast optics, only those lumens that remained in focus throughout an experiment were included. During exposure to purinergic agonists, lumen diameters were measured when the change in responsive vessels was maximal.

\section{Chemicals}

Unless otherwise noted, chemicals were from Sigma/RBI (St Louis, MO, USA).

\section{Statistics}

Data are given as means \pm S.E.M. Unless otherwise noted, probability was evaluated by Student's $t$ test, paired or unpaired, as appropriate.

\section{RESULTS}

\section{ATP-induced changes in pericyte currents}

To test the hypothesis that extracellular ATP regulates the physiology of the pericyte-containing microvasculature, we used the perforated-patch technique to monitor the ionic currents of pericytes located on microvessels freshly isolated from the rat retina. As illustrated in Fig. $1 A-C$, exposure of a microvessel to ATP $(1 \mathrm{~mm})$ initially caused an increase in both the steady-state and the transient inward currents. Subsequently, these inward currents and an outward conductance decreased as the cell capacitive currents also diminished. These effects of ATP were reversible, although immediately after cessation of ATP exposure an outward current briefly caused pericytes to hyperpolarize beyond the resting membrane potential (Fig. 1D). 

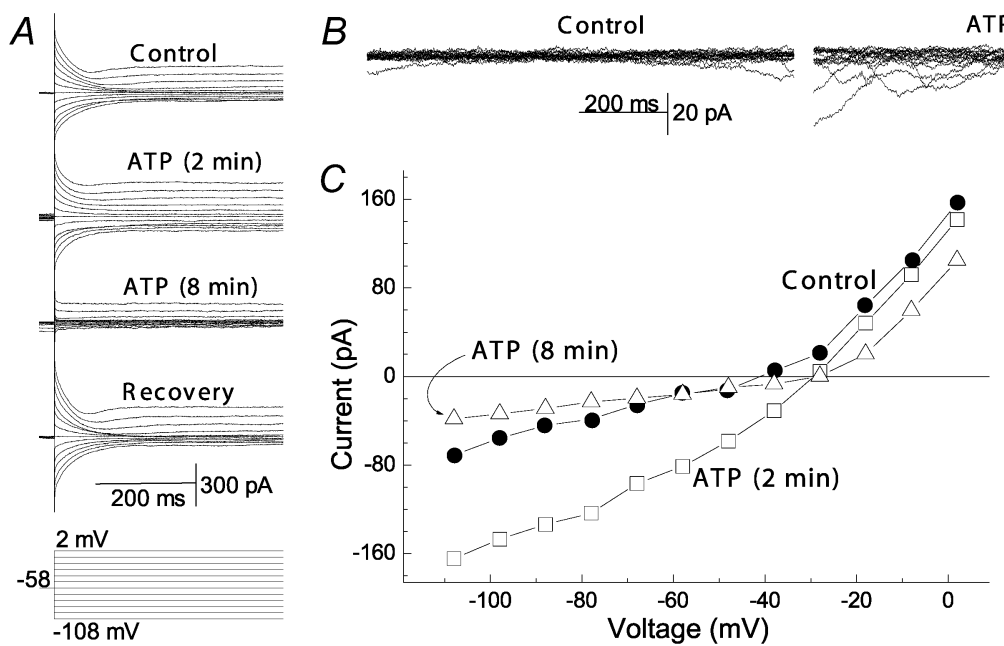

ATP (2 min)

ATP (8min)

Figure 1. Effect of ATP on retinal pericyte currents

$A$, current traces before and during exposure to ATP $(1 \mathrm{mM})$. The clamp protocol is shown below. Currents were monitored using the perforated-patch recording technique. Times indicate the interval after onset of exposure of isolated retinal microvessels to ATP. $B$, in each panel, 17 current traces are superimposed to show the transient inward currents recorded at a holding potential of $-58 \mathrm{mV}$ before (Control) and 2 and $8 \mathrm{~min}$ after the onset of ATP exposure. $C, I-V$ plots of the steady-state currents shown in $A . D, I-V$ plots of the steady-state currents of this pericyte 2 and 19 min after cessation of exposure to ATP. ATP caused changes in both the steady-state and transient pericyte currents.

We quantified these effects of ATP in a series of six sampled pericytes. During the initial minute of exposure to ATP, the steady-state inward current (measured at $-103 \mathrm{mV}$ ) progressively increased from $-82 \pm 19$ to $-175 \pm 14 \mathrm{pA}(P=0.006)$. In addition, there was more than a doubling, from $4.9 \pm 1$ to $10.0 \pm 2 \mathrm{pC}(P=0.031)$, of the net charge transfer associated with the transient inward currents, which are generated by calcium-activated chloride $\left(\mathrm{Cl}_{\mathrm{Ca}}\right)$ channels (Sakagami et al. 1999; Wu et al. 2003). Also during this time, the membrane potential of the sampled pericytes depolarized significantly $(P<0.034)$ from $-41 \pm 1$ to $-33 \pm 3 \mathrm{mV}$.

Over the next 2-5 min of exposure to ATP, the steady-state inward current of the six sampled pericytes decreased to an amplitude that was $44 \pm 7 \%(P=0.002)$ less than the control level. Similarly, there was a $40 \pm 10 \%(P=0.012)$ decrease in the amplitude of the outward pericyte current. In addition, the net charge transfer during the transient
$\mathrm{Cl}_{\mathrm{Ca}}$ currents decreased to $4.7 \pm 0.5 \mathrm{pC}$, which was near the control value. Throughout this period, the membrane potential of the sampled pericytes remained depolarized by $7 \pm 3 \mathrm{mV}$ from the resting level. No additional changes in the ionic currents or membrane potential were detected $(P>0.3)$ during $16 \pm 2$ min of ATP exposure.

Immediately after cessation of exposure to ATP, the six sampled pericytes transiently hyperpolarized beyond their resting membrane potentials. A maximal hyperpolarization of $-71 \pm 7 \mathrm{mV}$ was reached $2.7 \pm 0.6 \mathrm{~min}$ after withdrawal of ATP. Gradually, the membrane potential and current-voltage relations of the sampled pericytes returned to the control state, which was reached $23 \pm 3 \mathrm{~min}$ after termination of exposure to ATP.

\section{P2 $\mathrm{X}_{7}$ receptors}

To help identify the receptors that mediated the effects of ATP on pericyte physiology, we compared the efficacy of various purinergic agonists (Fig. 2). We found that $100 \mu \mathrm{M}$

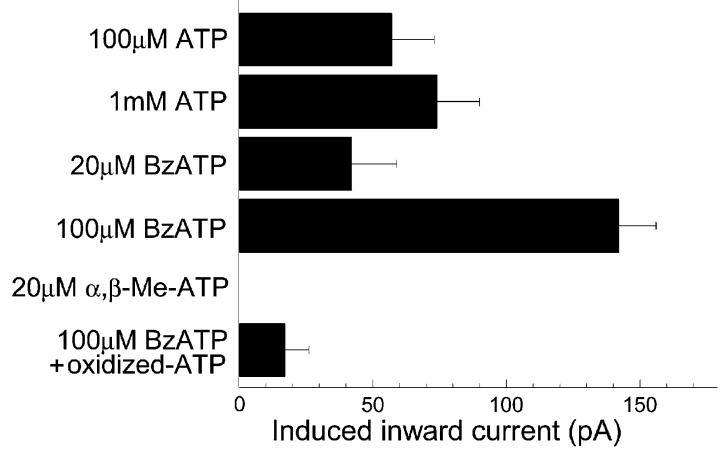

\section{Figure 2. Pharmacological evidence for $\mathrm{P}_{2} \mathrm{X}_{7}$ receptors}

Amplitudes of the induced inward current in pericytes $\sim 2$ min after the onset of exposure to a purinergic agonist. Currents were measured at $-103 \mathrm{mV}$. For each experimental condition, $7 \pm 3$ pericytes were assayed. Abbreviations: BzATP, benzoylbenzoyl-ATP; $\alpha, \beta$-Me-ATP, $\alpha, \beta$-methylene-ATP. In experiments using oxidized ATP, microvessels were incubated for $2 \mathrm{~h}$ at $37^{\circ} \mathrm{C}$ with $300 \mu \mathrm{M}$ of this $\mathrm{P} 2 \mathrm{X}_{7}$ antagonist prior to the addition of BzATP. The relative potencies, BzATP $>$ ATP $>>\alpha, \beta$-methylene-ATP, and the inhibition by oxidized $\mathrm{ATP}$ are consistent with an effect mediated via $\mathrm{P} 2 \mathrm{X}_{7}$ receptors. 
$A$
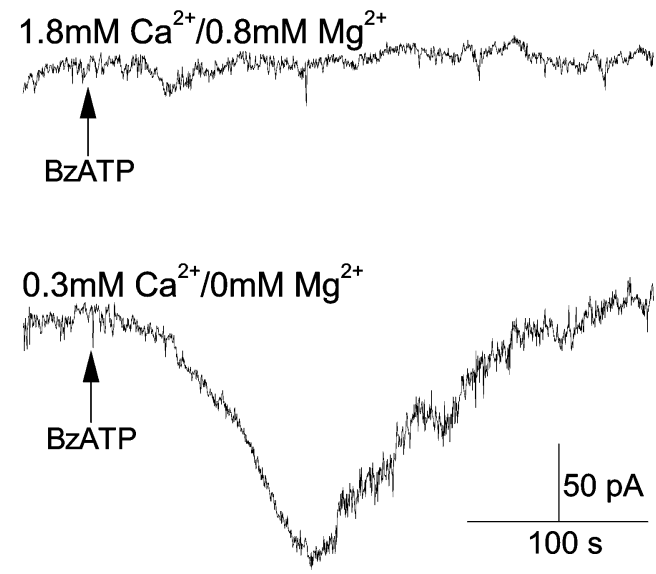

$B$

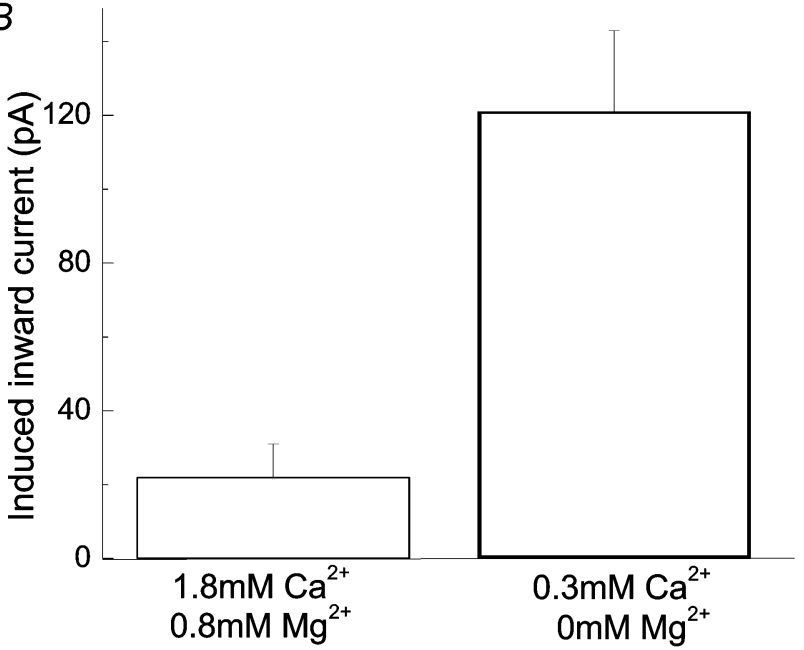

Figure 3. Effect of divalent cations

$A$, pericyte currents monitored at a holding potential of $-103 \mathrm{mV}$. Responses to $10 \mu \mathrm{M} \mathrm{BzATP}$ were monitored in Solution A, which contained $0.8 \mathrm{~mm}$ magnesium and $1.8 \mathrm{~mm}$ calcium, and also in a modified version of Solution A in which there was no magnesium and only $0.3 \mathrm{~mm}$ calcium. $B$, summary of four experiments done as in $A$. The inhibitory effect of these divalent cations is a characteristic of $\mathrm{P}_{2} \mathrm{X}_{7}$ receptormediated responses.

benzoylbenzoyl-ATP (BzATP) induced an inward current that was 2.5 -fold larger $(P=0.008)$ than the current activated during exposure to $100 \mu \mathrm{M}$ ATP. Also, $100 \mu \mathrm{M}$ BzATP was nearly twice as effective as $1 \mathrm{mM}$ ATP $(P=0.020)$. The greater potency of BzATP relative to ATP pointed to a role for $\mathrm{P}_{2} \mathrm{X}_{7}$ receptors (North \& Surprenant, 2000). However, because BzATP also activates $P_{2} X_{1}$ receptors (North \& Surprenant, 2000), we tested the effect of $\alpha, \beta$-methylene-ATP, which is a relatively specific agonist for the $\mathrm{P} 2 \mathrm{X}_{1}$ receptors (North \& Surprenant, 2000 ). The lack of a detectable effect of $\alpha, \beta$-methlyeneATP (Fig. 2) supported the conclusion that BzATP activated $\mathrm{P} 2 \mathrm{X}_{7}$, not $\mathrm{P} 2 \mathrm{X}_{1}$, receptors in the retinal microvessels. Further evidence for functional $\mathrm{P}_{2} \mathrm{X}_{7}$ receptors was that oxidized ATP (Fig. 2), which is a blocker of this type of purinergic receptor (Murgia et al. 1993), markedly decreased $(P<0.001, n=3)$ the inward current induced by BzATP. Taken together, our pharmacological experiments indicate that there are functional $\mathrm{P} 2 \mathrm{X}_{7}$ receptors in the pericytecontaining microvasculature of the retina.

To obtain further evidence for $\mathrm{P}_{2} \mathrm{X}_{7}$ receptors, we tested the effect of divalent cations on the amplitude of the inward current induced by BzATP. This was of interest because a characteristic of the $\mathrm{P}_{2} \mathrm{X}_{7}$ receptor is that divalent cations diminish the effectiveness of ATP and BzATP (North, 2002). Consistent with a role for $\mathrm{P}_{2} \mathrm{X}_{7}$ receptors, exposure of the isolated retinal microvessels to a magnesium-free/low calcium perfusate resulted in a more than 5 -fold increase $(P<0.001, n=3)$ in the amplitude of the inward current induced by $10 \mu \mathrm{M}$ BzATP (Fig. 3 ).

Not only does the binding of an agonist to a $\mathrm{P} 2 \mathrm{X}_{7}$ receptor result in ion channel opening, but sustained activation of these receptors in many types of cells results in the formation of a transmembrane pore, which is permeable to molecules of up to $900 \mathrm{Da}$ (North, 2002). To establish

\section{Figure 4. Effect of BzATP on the} uptake of YO-PRO-1

$A$, cellular fluorescence versus time in freshly isolated microvessels exposed to $100 \mu \mathrm{M}$ BzATP in the presence of $5 \mu \mathrm{M}$ YO-PRO-1. Each point is the mean of 13 microvascular cells. $B$, photomicrographs showing fluorescence in microvessels at $1 \mathrm{~min}$ (top) and $60 \mathrm{~min}$ (bottom) after the onset of exposure to BzATP. Uptake of this 629 Da molecule is consistent with the opening of membrane pores during activation of $\mathrm{P} 2 \mathrm{X}_{7}$ receptors.

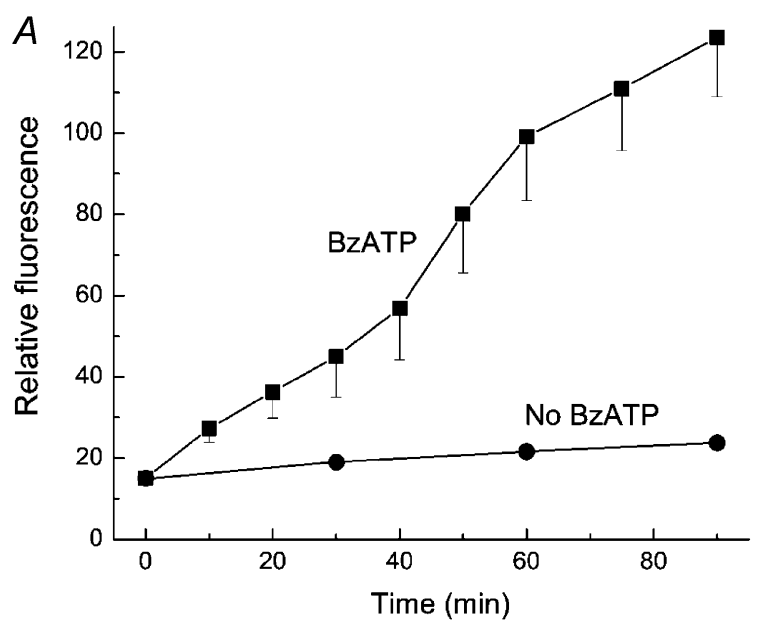

B
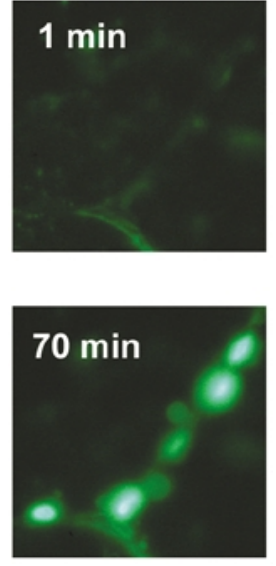
whether pores form in retinal microvascular cells during activation of $\mathrm{P}_{2} \mathrm{X}_{7}$ receptors, we exposed freshly isolated microvessels to BzATP $(100 \mu \mathrm{M})$ in the presence of the propidium analogue, YO-PRO-1 (629 Da), which is a fluorescent dye that binds to nucleic acids. By measuring the change in cell fluorescence, we detected a substantial uptake of YO-PRO-1 when BzATP was in the bathing solution (Fig. 4). This contrasted with a minimal change in fluorescence in cells of isolated microvessels that were maintained in the absence of BzATP. The presence of this large molecular mass dye within the microvascular cells exposed to BzATP is consistent with transmembrane pores being formed during the activation of $\mathrm{P} 2 \mathrm{X}_{7}$ receptors. The uptake of YO-PRO-1 during BzATP-exposure does not appear to be due to the depolarization caused by this $\mathrm{P}_{2} \mathrm{X}_{7}$ agonist because a bathing solution containing $100 \mathrm{mM}$ potassium (solution B plus $5 \mu \mathrm{M}$ YO-PRO-1) did not significantly ( $P=0.7, n=5)$ increase fluorescence of the microvascular cells. In further agreement with the retinal microvasculature having $\mathrm{P}_{2} \mathrm{X}_{7}$ receptors, isolated microvessels stained positively with an antibody to this purinergic receptor (Fig. 5). Thus, it appears likely that pericyte-containing microvessels of the rat retina express functional $\mathrm{P} 2 \mathrm{X}_{7}$ receptors.

Does activation of $\mathrm{P} 2 \mathrm{X}_{7}$ receptors account for all of the ATP-induced changes that were observed in pericytes? We found in each of 20 sampled pericytes that activation of $\mathrm{P}_{2} \mathrm{X}_{7}$ receptors by BzATP $(100 \mu \mathrm{M})$ qualitatively mimicked most, but not all, of the effects of ATP. Similar to ATP, exposure of microvessels to BzATP initially induced an increase in the steady-state inward current (Fig. 6A), which caused the membrane potential of the sampled pericytes to decrease from $-42 \pm 1$ to $-27 \pm 1 \mathrm{mV}(P<0.001)$. Subsequently, both inward and outward currents decreased as the cell capacitive current diminished (Fig. $6 A$ and $B$ ); associated with these changes, the voltage remained depolarized. Also similar to ATP, cessation of exposure to BzATP caused the membrane to hyperpolarize transiently to $-75 \pm 4 \mathrm{mV}$ before returning to the resting level. In a series of 20 recordings, BzATP always affected the steady-
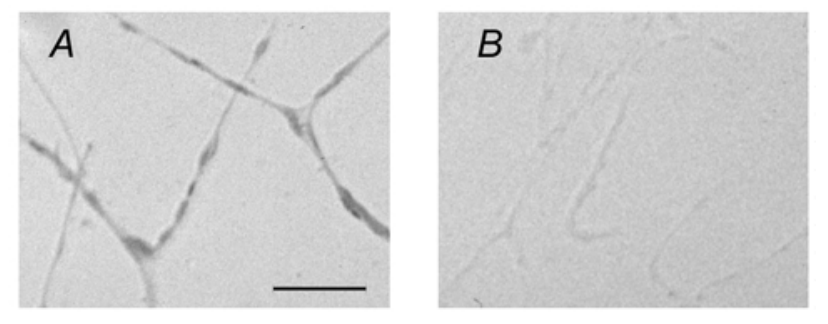

\section{Figure 5. Immunocytochemical evidence for $\mathrm{P}_{2} \mathrm{X}_{7}$ receptors}

$A$, isolated microvessels stained with an anti-P2X $\mathrm{X}_{7}$ antibody. Bar shows $50 \mu \mathrm{m}$. $B$, minimal immunoreactivity when the primary antibody was omitted from the protocol. state currents and pericyte membrane potential in a manner similar to ATP. However, in contrast to ATP, exposure to BzATP did not significantly $(P>0.6, n=20)$ activate the transient $\mathrm{Cl}_{\mathrm{Ca}}$ currents.

\section{UTP-activated receptors}

By what mechanism does ATP activate $\mathrm{Cl}_{\mathrm{Ca}}$ currents in the retinal microvasculature? Because BzATP did not activate these transient currents, we postulated that $\mathrm{Cl}_{\mathrm{Ca}}$ channel activity was regulated, not by $\mathrm{P} 2 \mathrm{X}_{7}$ receptors, but rather via a different type of purinergic receptor. To help test this hypothesis, we exposed retinal microvessels to UTP (Fig. 7A), which is an agonist for certain receptors in the P2Y family (von Kugelgen \& Wetter, 2000). With exposure of retinal microvessels to $30 \mu \mathrm{M}$ UTP, the net charge transfer due the $\mathrm{Cl}_{\mathrm{Ca}}$ currents increased significantly $(P<0.001, n=7)$ from $3.7 \pm 0.4$ to $10.0 \pm 0.7 \mathrm{pC}$. In contrast to mimicking the action of ATP on the $\mathrm{Cl}_{\mathrm{Ca}}$ currents, UTP did not mimic the effects of ATP on the initial increase in the steady-state inward current or on the subsequent diminution of ionic and the cell capacitive currents in retinal pericytes. Because UTP is a ligand for $\mathrm{P} 2 \mathrm{Y} 2$ and P2Y4 receptors, we tested the effect of suramin,
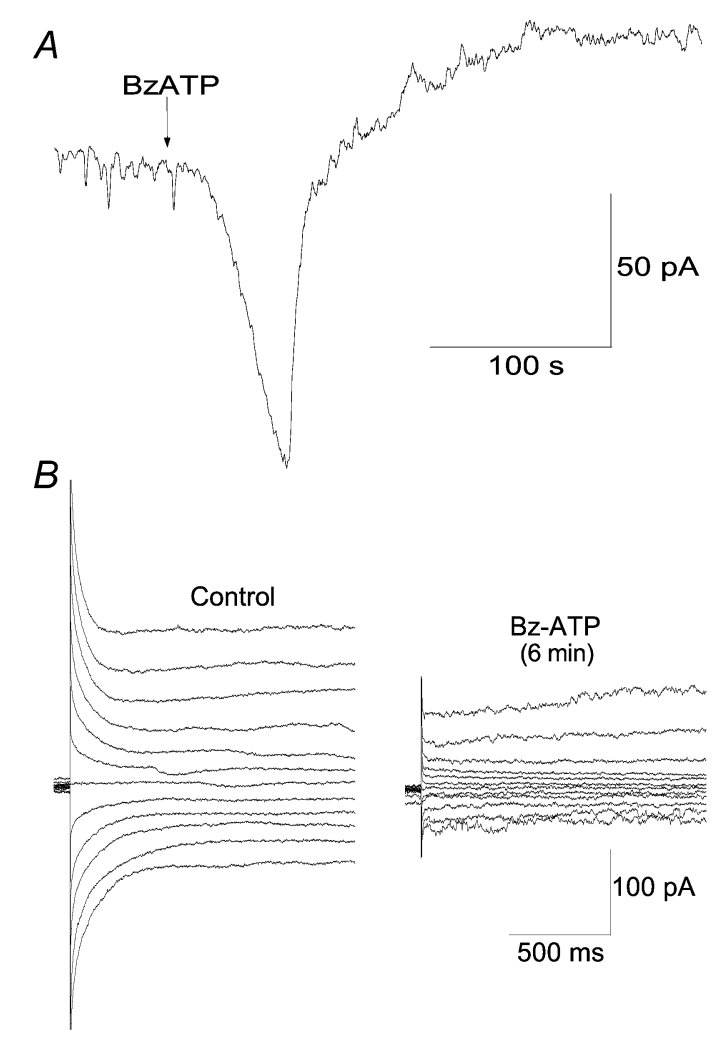

\section{Figure 6. Effect of BzATP on the pericyte currents}

$A$, continuous current record of a pericyte voltage clamped at $-103 \mathrm{mV}$. The arrow shows the onset of exposure to $100 \mu \mathrm{M}$ BzATP. $B$, current traces for the same pericyte as in $A$ before and 6 min after the onset of exposure to BzATP. The voltage-step protocol was as shown in Fig. $1 A$. This $\mathrm{P}_{2} \mathrm{X}_{7}$ agonist initially caused an increase in the steady-state inward current and then a decrease in the ionic and cell capacitive currents. 
which is reported to inhibit P2Y2, but not P2Y4, receptors (North \& Surprenant, 2000). We did not detect a significant $(P=0.4, n=4)$ effect of this antagonist $(10 \mu \mathrm{M})$ on the activation of $\mathrm{Cl}_{\mathrm{Ca}}$ currents during exposure of microvessels to $1 \mathrm{mM}$ ATP. This finding is consistent with $\mathrm{P} 2 \mathrm{Y} 4$ receptors playing a role in the regulation of $\mathrm{Cl}_{\mathrm{Ca}}$ channel activity.

By what mechanism does the activation of the UTPsensitive receptors regulate $\mathrm{Cl}_{\mathrm{Ca}}$ channels? Because this nucleotide induces the release of intracellularly stored calcium in many types of cells (von Kugelgen \& Wetter, 2000), we tested this possibility in the retinal microvasculature. Consistent with a role for calcium release, UTP $(30 \mu \mathrm{M})$ caused pericyte calcium levels to rise transiently while microvessels were perfused with a calciumfree solution (Fig. $7 B$ ). Specifically, in each of the 14 monitored pericytes, a significant $(P<0.001)$ increase in the calcium concentration was detected. In these cells the peak increase in calcium was $56 \pm 15 \mathrm{nM}$. At present, it is unclear why $\mathrm{Cl}_{\mathrm{Ca}}$ channels were activated by the release of stored calcium, but an influx of calcium via $\mathrm{P}_{2} \mathrm{X}_{7}$ receptors/channels was ineffective. Perhaps future studies will find that $\mathrm{Cl}_{\mathrm{Ca}}$ channels are located closer to calcium release sites than to sites of calcium influx via $\mathrm{P}_{2} \mathrm{X}_{7}$ receptor/channels.

Taken together, our experiments indicate that the effects of ATP on the physiology of the pericyte-containing microvasculature of the retina are mediated via multiple purinergic receptors. The activation by ATP of the $\mathrm{Cl}_{\mathrm{Ca}}$ currents is likely to be mediated via UTP-binding receptors, and the ATP-induced changes in steady-state currents are linked with the activation of $\mathrm{P} 2 \mathrm{X}_{7}$ receptors.

\section{Inhibition of cell-to-cell coupling}

After the initial increase in inward pericyte current, both inward and outward currents decreased during exposure to ATP (Fig. 1A-C) or BzATP (Fig. 6). By what mechanism did the sustained activation of $\mathrm{P} 2 \mathrm{X}_{7}$ receptors cause this decrease in currents? Because gap junction pathways couple retinal pericytes with neighbouring vascular cells (Oku et al. 2001; Kawamura et al. 2002), we considered the possibility that the decrease in current during sustained $\mathrm{P}_{2} \mathrm{X}_{7}$ receptor activation was due to the sampled pericytes becoming functionally uncoupled. As a result, currents generated in neighbouring cells would no longer be electrotonically transmitted to the sampled pericytes. This seemed to be a reasonable possibility because a closure of gap junction pathways is associated with a similar decrease in pericyte currents when retinal microvessels are exposed to another vasoactive molecule, endothelin-1 (Oku et al. 2001).

Our electrophysiological experiments supported the hypothesis that activation of $\mathrm{P}_{2} \mathrm{X}_{7}$ receptors caused a functional uncoupling of retinal microvascular cells.
Consistent with this idea, sustained exposure of isolated retinal microvessels to BzATP $(100 \mu \mathrm{M})$ always $(n=23)$ resulted in an attenuation of the cell capacitive currents (Fig. 6B), as is predicted by a modelling analysis of single and coupled cells (Lindau \& Neher, 1988). To obtain more direct evidence that this $\mathrm{P}_{2} \mathrm{X}_{7}$ agonist caused microvascular cells to uncouple, we simultaneously recorded from pairs of pericytes located on freshly isolated microvessels (Fig. 8). For two pairs of pericytes, we successfully tested communication during exposure to BzATP $(100 \mu \mathrm{M})$. (One pericyte pair was separated by $90 \mu \mathrm{m}$, the other by $240 \mu \mathrm{m}$.) The $\mathrm{P} 2 \mathrm{X}_{7}$ agonist reversibly reduced electrotonic transmission by $88 \pm 10 \%(P=0.029)$. More specifically, the fraction of the voltage change transmitted between the sampled pericytes decreased from $0.67 \pm 0.02$ to $0.08 \pm 0.07$. Associated with the decrease in electronic transmission, the capacitive and ionic currents of both cells in a sampled pair decreased in a similar manner (Fig. $8 C$ and $D$ ). These findings support the hypothesis that a reduction in cell-to-cell communication during activation of $\mathrm{P} 2 \mathrm{X}_{7}$ receptors accounts for the generalized decrease in pericyte currents observed during exposure to BzATP or ATP.

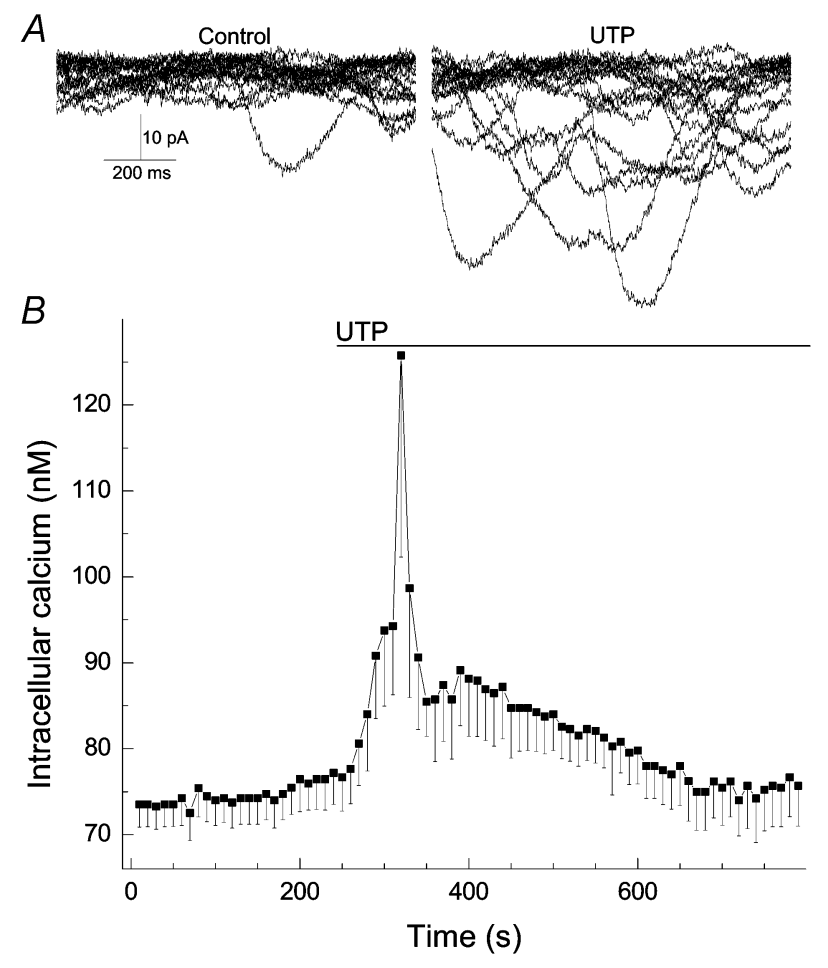

\section{Figure 7. Effect of UTP on retinal pericytes}

$A$, in each panel, 17 current traces are superimposed to show the transient inward currents before (Control) and 4 min after the onset of exposure to $30 \mu \mathrm{M}$ UTP. The holding potential was $-103 \mathrm{mV} . \mathrm{B}$, mean intracellular calcium concentration of pericytes $(n=4)$ before and during (bar) addition of $1 \mathrm{mM} \mathrm{UTP}$ to a calcium-free bathing solution (Solution $\mathrm{A}$ without $\mathrm{CaCl}_{2}$ and with 3 mM EGTA). UTP caused the release of stored calcium and the activation of $\mathrm{Cl}_{\mathrm{Ca}}$ currents. 
In this study, we began to test hypotheses concerning the mechanisms by which activation of $\mathrm{P} 2 \mathrm{X}_{7}$ receptors causes an uncoupling of microvascular cells. We considered the possibility that calcium, which passes through P2X receptors (North \& Surprenant, 2000), may play a role. In a series of experiments, incubation of isolated microvessels for $26 \pm 2 \min (n=3)$ in solution A supplemented with
$50 \mu \mathrm{M}$ BAPTA-AM (1,2-bis( $O$-aminophenoxy)ethane$N, N, N^{\prime}, N^{\prime}$-tetraacetic acid tetra(acetoxymethyl) ester) prevented a BzATP-induced shortening of the cell capacitive current, which as noted above is an electrophysiological parameter that is useful in detecting cell uncoupling (Postma et al. 1998). This suggests that a rise in intracellular calcium may be an important step leading to the

\section{$A$}

\section{Patch-clamp amplifier \#2}

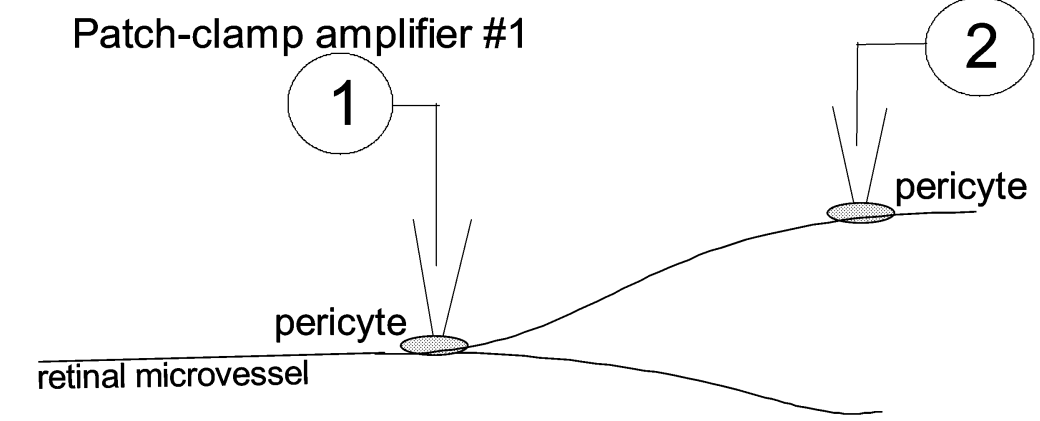

$B$
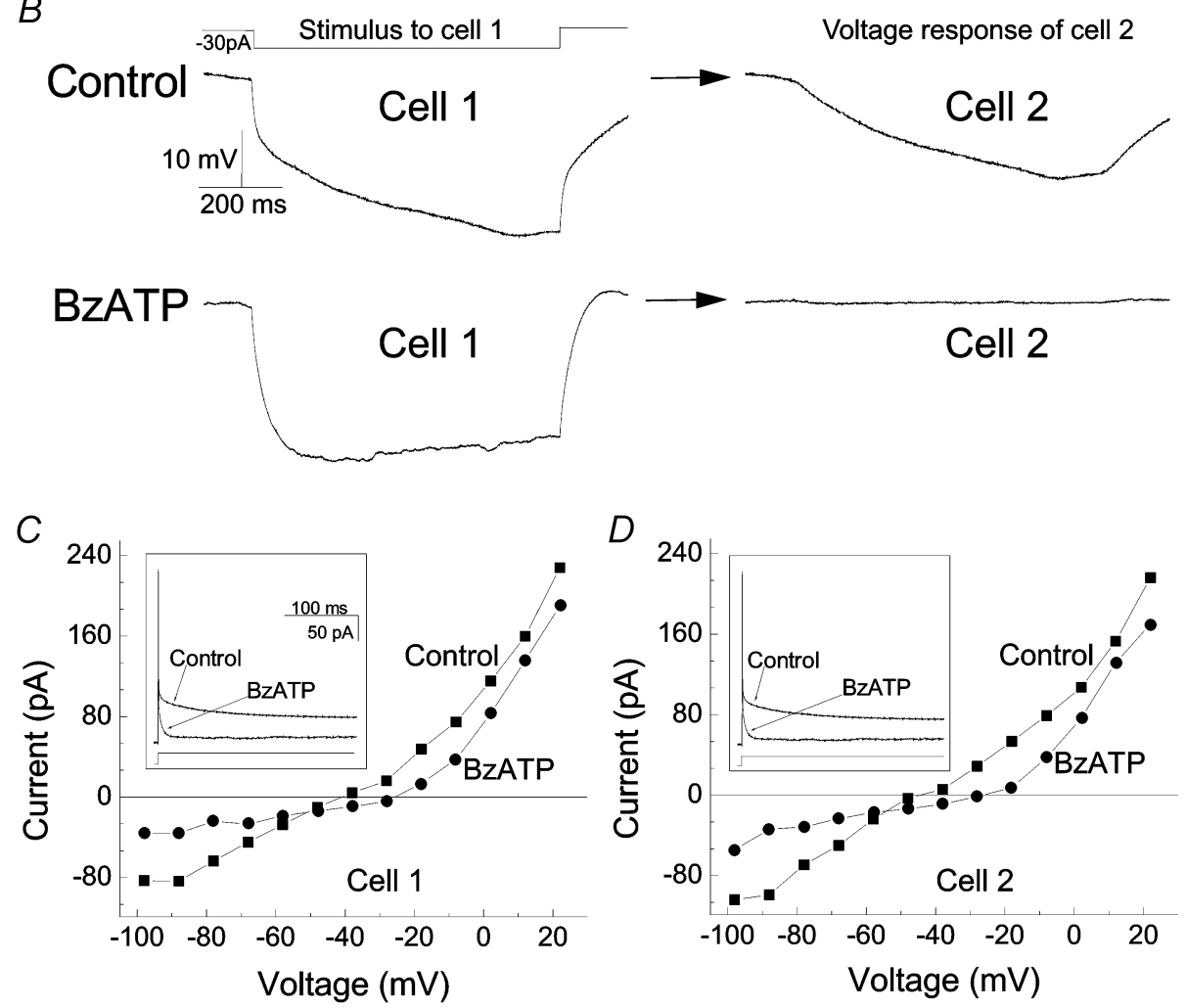

\section{Figure 8. Effect of $\mathrm{P} 2 \mathrm{X}_{7}$ activation on cell-to-cell coupling within retinal microvessels}

$A$, schematic illustrating the positioning of two perforated-patch pipettes, which were located $240 \mu \mathrm{m}$ apart on a freshly isolated microvessel. A current step was applied to one of the sampled pericytes (cell 1 ), and the membrane potentials of both pericytes were monitored. $B$, voltage traces recorded in the two sampled pericytes under control conditions (top) and $2.5 \mathrm{~min}$ after exposure to $100 \mu \mathrm{M}$ BzATP (bottom). The protocol for the $-30 \mathrm{pA}$ stimulus that was applied to cell 1 is shown above this cell's voltage traces. The arrows point to the voltage traces of the responder cell (cell 2). $C, I-V$ plots of cell 1 before and $5 \mathrm{~min}$ after the onset of exposure to BzATP. Inset, two superimposed current traces recorded from cell 1 before (control) and 5 min after the onset of exposure to BzATP. The timing of the $10 \mathrm{pA}$ current step is shown below the traces. $D$, similar to $C$, but for cell 2, before and $8 \mathrm{~min}$ after the onset of exposure to BzATP. Note that both sampled pericytes responded similarly. Exposure to BzATP markedly reduced cell-to-cell electrotonic transmission within the pericyte-containing microvessel. 
inhibition of electrotonic transmission during $\mathrm{P}_{2} \mathrm{X}_{7}$ receptor activation. In other experiments, we assessed the effect of the PKC inhibitor, chelerythrine, on the BzATP-induced uncoupling. This was of interest because PKC can be activated by calcium and appears to mediate the gap junction closure that is observed during exposure of isolated retinal microvessels to endothlin-1 (Kawamura et al. 2002) and that is induced in retinal microvessels soon after the onset of streptozotocin-induced diabetes (Oku et al. 2001). However, in contrast to its inhibitory effect on endothelin- and diabetes-induced uncoupling, chelerythrine $(1 \mu \mathrm{M})$ did not prevent an attenuation of the cell capacitive currents during exposure of microvessels $(n=3)$ to $100 \mu \mathrm{M}$ BzATP. At present, the sequence of molecular events linking $\mathrm{P}_{2} \mathrm{X}_{7}$ receptor activation and gap junction closure remains to be defined.

\section{$\mathrm{Na}^{+}, \mathrm{K}^{+}$-ATPase activation}

What is the mechanism by which pericytes were hyperpolarized approximately $30 \mathrm{mV}$ beyond their resting membrane potential soon after cessation of exposure to ATP (Fig. 1D)? This voltage increase was linked with $\mathrm{P}_{2} \mathrm{X}_{7}$ receptors having been activated because a similar hyperpolarization, from $-27 \pm 2$ to $-76 \pm 3 \mathrm{mV}(n=12)$, occurred after washout of BzATP. In contrast, the membrane potential of sampled pericytes did not hyperpolarize beyond the resting level after UTP exposure $(n=3)$.

Examination of the current-voltage relations of sampled pericytes showed that this hyperpolarization after termination of $\mathrm{P} 2 \mathrm{X}_{7}$ receptor activation was due to an outward current (Fig. 9). In preliminary experiments, various potassium channel blockers, such as barium, glibencamide, and linopirdin, failed to inhibit this outward current. However, this outward current was reversibly blocked by ouabain (Fig. 9), which is an inhibitor of the eletrogenic $\mathrm{Na}^{+}-\mathrm{K}^{+}$pump. During the
post-BzATP hyperpolarization, the addition of ouabain $(5 \mathrm{~mm})$ to the perfusate caused the pericyte membrane potential to decrease to $-33 \pm 2 \mathrm{mV}(P<0.001, n=5)$. This blocking effect of ouabain was reversible.

Based on these experiments, we conclude that stimulation of the electrogenic $\mathrm{Na}^{+}-\mathrm{K}^{+}$pump accounts for the marked hyperpolarization that was always observed after washout of $1 \mathrm{~mm} \operatorname{ATP}(n=6)$ or $100 \mu \mathrm{M} \operatorname{BzATP}(n=12)$. Although the $\mathrm{Na}^{+}-\mathrm{K}^{+}$pump was active after termination of $\mathrm{P} 2 \mathrm{X}_{7}$ receptor activation, we did not detect a significant $(P>0.6)$ effect of ouabain on the pericyte membrane potential under control conditions $(n=3)$ or during exposure to $100 \mu \mathrm{M} \operatorname{BzATP}(n=3)$. At present, it is unclear why the activity of the $\mathrm{Na}^{+}-\mathrm{K}^{+}$pump was minimal while $\mathrm{P} 2 \mathrm{X}_{7}$ receptors were being activated. Perhaps, future studies will find that the large transmembrane pores (Fig. 4), which are opened during sustained activation of $\mathrm{P}_{2} \mathrm{X}_{7}$ receptors, caused an efflux of molecules that are essential for the function of this electrogenic pump. The activity of this pump after $\mathrm{P} 2 \mathrm{X}_{7}$ receptor activation may due to disruption of intracellular sodium and potassium concentrations during the opening of the $\mathrm{P} 2 \mathrm{X}_{7}$ channels/pores. We speculate that activation of the $\mathrm{Na}^{+}-\mathrm{K}^{+}$pump minimizes microvascular cell injury by rapidly returning intracellular sodium and potassium concentrations towards normal after the activation of $\mathrm{P} 2 \mathrm{X}_{7}$ receptors.

\section{Pericyte contraction}

What is the functional role of $\mathrm{P}_{2} \mathrm{X}_{7}$ receptors in the pericyte-containing retinal microvasculature? Because intracellular calcium regulates pericyte contractility $(\mathrm{Wu}$ et al. 2003), one possibility is that a nucleotide-induced increase in calcium levels causes pericytes to contract and thereby microvascular lumens to narrow and capillary perfusion to decrease. To begin to test this possibility, we wished to confirm that the activation of $\mathrm{P} 2 \mathrm{X}_{7}$ receptor/ channels in retinal microvessels, as in other cell types,
Figure 9. Effect of ouabain on the hyperpolarizing current generated after termination of $\mathbf{P} 2 \mathbf{X}_{7}$ receptor activation

$I-V$ plots of a pericyte $5 \mathrm{~min}$ after the onset of exposure to $100 \mu \mathrm{M}$ BzATP (plot labelled 'BzATP'), 8 min after washout of BzATP (Post-BzATP), 2 min after the subsequent addition of $5 \mathrm{~mm}$ ouabain to the BzATP-free perfusate (Ouabain), and 10 min after washout of ouabain (Ouabain washout). For clarity, dotted lines were used for the BzATP and the ouabain washout $I-V$ curves. Inset, the difference between the Post-BzATP and Ouabain plots. Consistent with activation of the eletrogenic $\mathrm{Na}^{+}-\mathrm{K}^{+}$pump, ouabain blocked the large hyperpolarization that occurred after cessation of exposure to the $\mathrm{P} 2 \mathrm{X}_{7}$ agonist.

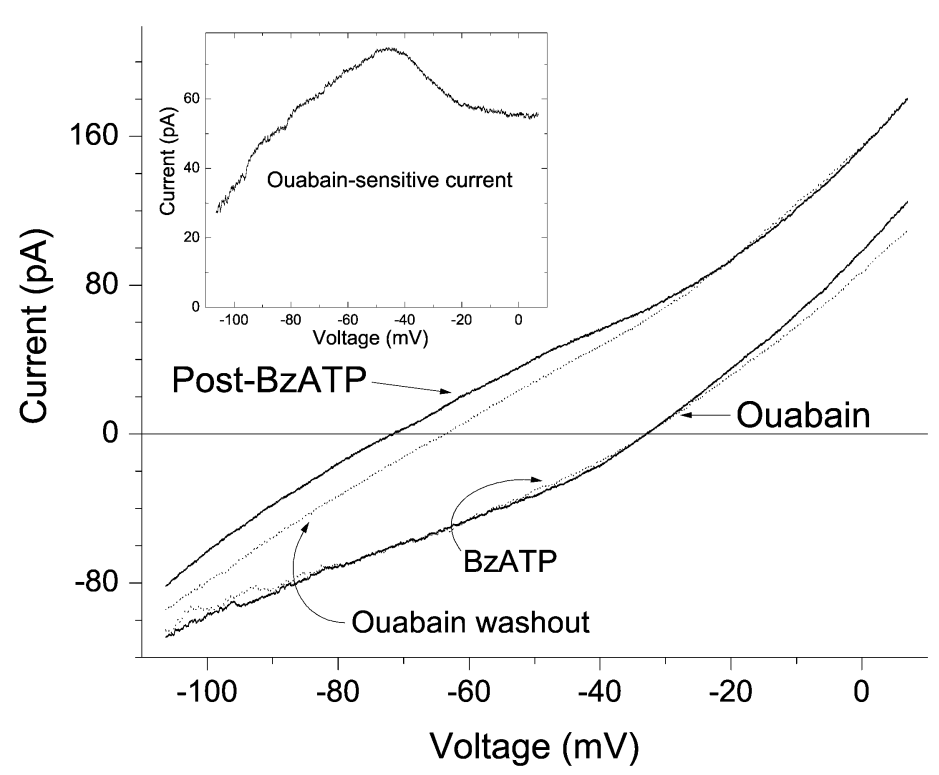


results in an influx of calcium. Consistent with this, exposure to BzATP was associated with an increase in the intracellular calcium concentration in each to 27 monitored pericytes. The increase in pericyte calcium was dependent upon extracellular calcium (Fig. 10).

Having found that the opening of $\mathrm{P} 2 \mathrm{X}_{7}$ receptor/channels provides pathways for the influx of calcium, we then used differential interference contrast optics and time-lapse photography to assess the effects of BzATP (100 $\mu \mathrm{M})$ on the contractile tone of pericytes located on freshly isolated retinal microvessels. We detected BzATP-induced contractions of one or more pericytes in nine of the ten microvascular complexes studied. Within a microvascular complex, contractions were detected in only a minority of the pericytes. Overall, $37 \%$ (39 of 106) of the monitored pericytes contracted in response to this $\mathrm{P}_{2} \mathrm{X}_{7}$ agonist. Unlike pericytes contacting in response to the activation of muscarnic receptors (Wu et al. 2003), pericytes with BzATP-induced contractions were not $(P=0.2)$ preferentially located near branch points within a microvascular complex.

To help establish that an elevation in the intracellular calcium concentration mediated the contractile response of pericytes, the effect of a cell-permeable calcium chelator, BAPTA-AM was tested. We initially used time-lapse photography to identify 11 pericytes that contracted in response to BzATP $(100 \mu \mathrm{M})$. Microvessels with contracting pericytes were then exposed for $25 \pm 1 \min (n=11)$ to Solution A supplemented with BAPTA-AM $(20 \mu \mathrm{M})$. Subsequently, re-exposure of the microvessels to BzATP evoked a contraction in only one of the 11 pericytes that had contracted previously. The inhibition by BAPTAAM of the BzATP-induced contractions was significant $(P<0.001$, Fisher's exact test $)$. In control experiments, a second exposure to BzATP again elicited pericyte contractions in each of ten microvessels that were not exposed to the calcium chelator after the initial demonstration of BzATP-induced concentrations. Our experiments using BAPTA support the idea that a rise in intracellular calcium links $\mathrm{P}_{2} \mathrm{X}_{7}$ receptor activation with pericyte contraction.

\section{Vasoconstriction}

We also assessed whether pericyte contraction caused the adjacent capillary lumen to narrow. In all cases $(n=13)$ in which both the contracting pericyte and the vascular lumen were in the focal plane of the differential interference microscope, a significant $(P \leqslant 0.036)$ decrease in the diameter of the lumen was observed as pericytes contracted in response to $100 \mu \mathrm{M}$ BzATP, $100 \mu \mathrm{M}$ UTP or $1 \mathrm{~mm}$ ATP (Fig. 11). We conclude that the activation of $\mathrm{P}_{2} \mathrm{X}_{7}$ and UTP-binding receptors by ATP elicits vasoconstriction of the pericyte-containing microvasculature of the retina.

\section{DISCUSSION}

Our results support the hypothesis that ATP serves as a vasoactive signal in the pericyte-containing microvasculature of the retina. Electrophysiological recordings, calcium imaging studies and time-lapse photography showed that activation of $\mathrm{P} 2 \mathrm{X}_{7}$ receptors affected pericytes in a number of ways. These included depolarization of the membrane potential, calcium influx and cellular contraction. UTP-activated receptors also affected these cells by releasing stored calcium, activating depolarizing $\mathrm{Cl}_{\mathrm{Ca}}$ channels and causing contraction. When pericytes contracted in response to activation of $\mathrm{P}_{2} \mathrm{X}_{7}$ or UTPbinding receptors, the adjacent capillary lumens narrowed. Thus, our experiments indicate that ATP is a vasoconstrictor in the pericyte-containing microvasculature of the retina.

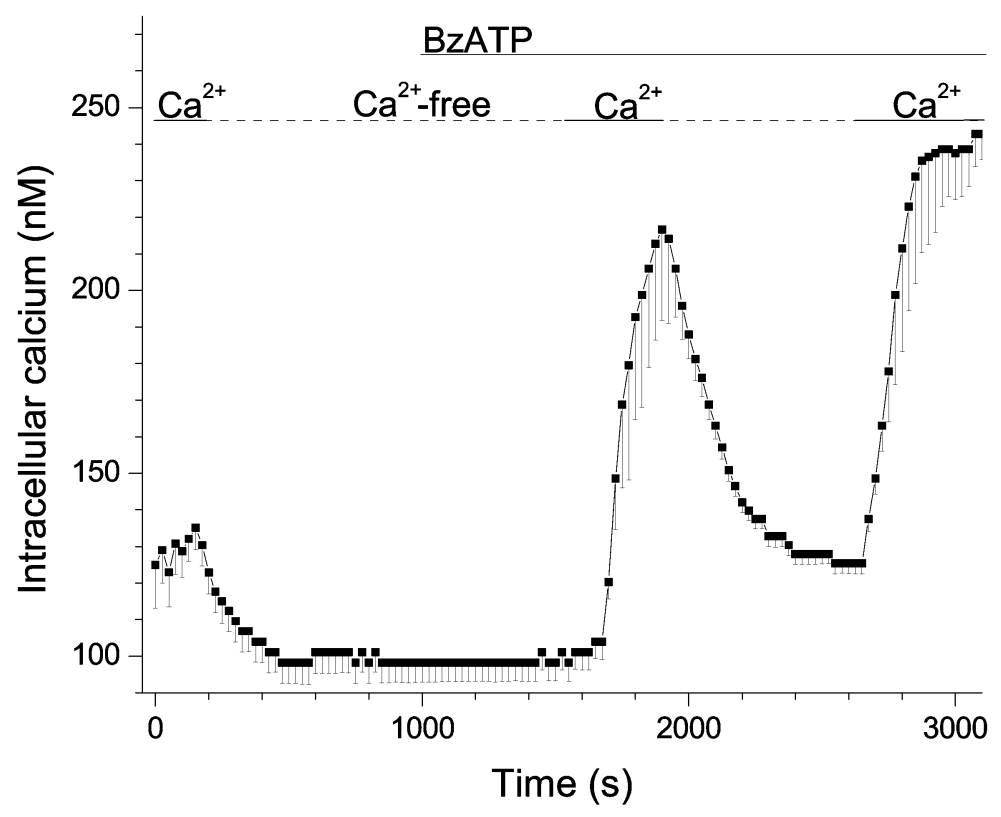

Figure 10. Effect of extracellular calcium on the BzATP-induced increase in pericyte calcium

The continuous portion of the bar located above the plot shows the periods during which the microvessel was exposed to a calcium-containing perfusate (Solution A). The dashed portion of this bar indicates when there was a calcium-free perfusate (Solution A lacking $\mathrm{CaCl}_{2}$ and containing 3 mM EGTA). The period of exposure to $\operatorname{BzATP}(100 \mu \mathrm{M})$ is indicated by the top bar. Each data point shows the mean of 6 sampled perictyes. The increase in pericyte calcium evoked by this $\mathrm{P}_{2} \mathrm{X}_{7}$ agonist was dependent on external calcium. 
ATP not only affected the physiology of individual vascular cells, but also regulated cell-to-cell communication. By activating $\mathrm{P}_{2} \mathrm{X}_{7}$ receptors, ATP profoundly inhibited electrotonic transmission within pericyte-containing microvessels. This regulation of intercellular communication may be an important, previously unrecognized, action of this nucleotide. Almost certainly, the extent to which a localized change in voltage is transmitted throughout the vascular network would affect the dynamics of capillary perfusion. We predict that while the gap junction pathways remain opened, a local depolarization induced by the focal release of ATP would spread electrotonically along the microvessel. However, with continued exposure to ATP, the resulting uncoupling of microvascular cells would limit the region of depolarization and contraction to the site of ATP release. Future experiments using focal ATP application should help to establish the spatial and temporal dynamics of the microvascular response to a localized activation of purinergic receptors.

Much remains to be learned about the mechanism by which the activation of $\mathrm{P} 2 \mathrm{X}_{7}$ receptors results in the closure of gap junctions within the pericyte-containing vessels of the retina. It appears unlikely that the decrease in intercellular communication was caused by the $12 \pm 2 \mathrm{mV}$ depolarization induced by the $\mathrm{P} 2 \mathrm{X}_{7}$ agonists because a similar $(P=0.49)$ decrease in the membrane potential during exposure to insulin-like growth factor-1 did not reduce cell coupling in isolated retinal microvessels (Sakagami et al. 1999). Rather than depolarization having a critical role, our experiments using a chelator of intracellular calcium suggest that the influx of this divalent cation via $\mathrm{P}_{2} \mathrm{X}_{7}$ receptor/channels is an initial step leading to gap junction closure. One consequence of raising the intracellular calcium concentration is the activation of $\mathrm{PKC}$, which can regulate gap junction pathways in the retinal microvasculature (Kawamura et al. 2001; Oku et al. 2001). However, unlike the inhibition of gap junction communication observed during exposure to endothelin-1 (Kawamura et al. 2002) and soon after the onset of diabetes (Oku et al. 2001), the BzATP-induced uncoupling of microvascular cells was not blocked by the PKC inhibitor chelerythrine. Thus, at present, the sequence of events linking an influx of calcium with the inhibition of cell-tocell communication in retinal microvasculature remains to be elucidated. One potentially fruitful line of study will be to identify calcium-dependent mechanisms that regulate the phosphorylation and thereby, the function of the connexins that form gap junctions in the retinal microvessels.

Our study also shows that there is a functional heterogeneity of retinal pericytes. While all sampled pericytes showed characteristic changes in their ionic currents and calcium levels during the activation of $\mathrm{P} 2 \mathrm{X}_{7}$ receptors, only $37 \%$ of the observed pericytes had detectable contractions.
Even though it is likely that limitations in the sensitivity of our contraction assay (time-lapse videos of differential interference contrast images) led to an underestimation of the number of contracting pericytes, it is evident that there are substantial qualitative differences in the contractile responses of these cells to $\mathrm{P}_{2} \mathrm{X}_{7}$ agonists. Our recent observation (K. Katsumura \& D. G. Puro, unpublished observations) that potassium-induced voltage changes also evoke detectable contractions in a similar $(P=0.36)$ minority $(42 \%)$ of pericytes suggests that the heterogeneity of pericyte contractility is due to events downstream from receptor activation. Although differing quantities of contractile proteins within pericytes (Nehls \& Drenckhahn, 1991) may account for our observations, more studies are needed to clarify the molecular basis for the functional heterogeneity of these cells. However, despite the need to clarify the mechanisms responsible for pericyte diversity, it is now clear that the functional heterogeneity of these cells means that the physiology of the retinal microvasculature is more complex that once thought.

Although it is well known that purinergic receptors are important in the circulatory system (Burnstock, 1990; Boarder \& Hourani, 1998; Oku et al. 2001), there are few previous studies of the role of these receptors in the pericyte-containing microvasculature. A study of cultured retinal pericytes did demonstrate that extracellular ATP caused these cells to depolarize (Wagner \& Wiederholt, 1996), although the involved receptors were not identified. The experiments reported in our study are the first to focus on the role of $\mathrm{P}_{2} \mathrm{X}_{7}$ receptors and UTP-activated receptors in pericyte-containing microvessels. Our finding that UTP is vasoactive in the retinal microvasculature is consistent with a substantial literature indicating that UTP-activated

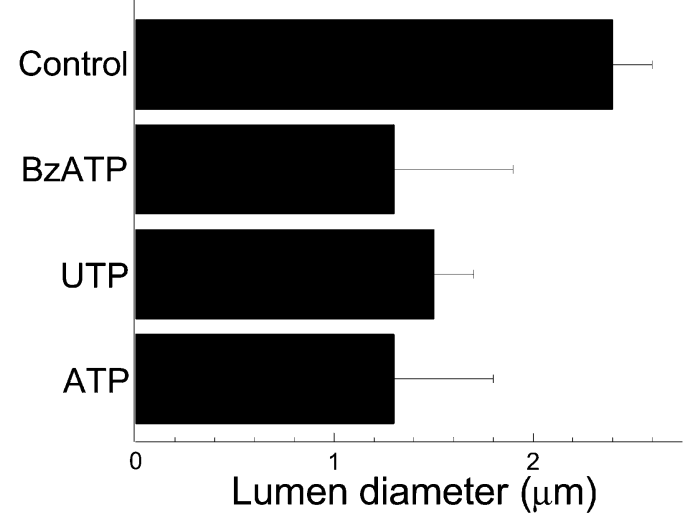

Figure 11. Effect of purinergic agonists on the lumen diameter of isolated retinal microvessels

For each experimental condition, $6 \pm 2$ vascular lumens were measured. Significant vasoconstriction was induced in pericytecontaining retinal microvessels by $100 \mu \mathrm{M}$ BzATP $(P=0.036)$, $30 \mu \mathrm{MUTP}(P=0.030)$ and $1 \mathrm{~mm} \operatorname{ATP}(P=0.027)$. 
receptors are important in the vascular system (Boarder \& Hourani, 1998). On the other hand, our evidence for functional $\mathrm{P} 2 \mathrm{X}_{7}$ receptors in microvessels was unexpected. At present, there are only a few reports of these receptors being located in the circulatory system; they have been identified in smooth muscle of surgically excised varicose saphenous veins (Cario-Toumaniantz et al. 1998) and in cultured aortic endothelial cells (von Albertini et al. 1998; Ramirez \& Kunze, 2002). Based on the findings presented here, we propose that the activation of $\mathrm{P}_{2} \mathrm{X}_{7}$ receptors regulates pericyte contractility, lumen diameter and thereby local perfusion in retinal capillaries. In addition, the inhibition of cell-to-cell communication is a newly discovered mechanism by which vasoactive signals, such as ATP, may regulate the regional distribution of oxygen and nutrients within the retina.

What are the sources of the extracellular ATP that could regulate capillary function? Although sympathetic nerves release ATP onto blood vessels in nearly all non-retinal vascular beds, the retina lacks autonomic input (Ye et al. 1990). Thus, locally released ATP must activate the purinergic receptors of the retinal vasculature. One local source of this nucleotide is the glia. ATP released by retinal glia cells is known to inhibit neuronal activity (Newman, 2003) and to propagate calcium waves from one glial cell to another (Newman, 2001). The close apposition of glial processes and microvessels supports the hypothesis that ATP may mediate glial-to-vascular communication, as well as serving as a glial-to-neuronal and glial-to-glial signal.

In addition to glial cells, another potential source of extracellular ATP is the vascular endothelium. In many tissues, shear stress in blood vessels causes endothelial cells to release ATP (Bodin et al. 1991). Also, this nucleotide is released by platelets when they become activated and by red blood cells when oxygen tension is low (Dietrich et al. 2000). Another possible source of this nucleotide is damaged cells from which high concentrations of intracellular ATP may leak (Le Feuvre et al. 2002). Thus, the activation of purinergic receptors by ATP may play a role in regulating pericyte-containing retinal microvessels under physiological and pathophysiological conditions.

Because technical challenges precluded an in vivo application of the electrophysiological and imaging methods used in this study, experiments with freshly isolated microvessels were essential to begin to clarify the mechanisms by which ATP regulates the pericyte-containing microvasculature. Clearly, it remains to be demonstrated that the observed effects of activating $\mathrm{P}_{2} \mathrm{X}_{7}$ receptors and UTP-activated receptors in isolated retinal microvessels also occur in vivo. In addition, it is not known whether the purinergic effects observed in retinal microvessels also occur in pericyte-containing microvessels in other vascular beds. Another unknown is whether there is sufficient extracellular ATP in vivo to activate $\mathrm{P} 2 \mathrm{X}_{7}$ receptors, which have $\mathrm{EC}_{50}$ values of $\sim 100 \mu \mathrm{M}$ (North \& Surprenant, 2000). However, ATP released into the limited space between the ensheathing glial processes and pericytes may reach a high concentration. Furthermore, substantial amounts of this nucleotide may be present at sites of platelet activation and cell damage.

In summary, our experiments indicate that $\mathrm{P}_{2} \mathrm{X}_{7}$ receptors and UTP-activated receptors regulate capillary function in the retina by eliciting vasoconstriction. The ability to study pericytes as integral components of a multicellular functional unit revealed that activation of $\mathrm{P}_{2} \mathrm{X}_{7}$ receptors not only alters the physiology of individual pericytes, but also inhibits gap junction communication within the microvascular network. As a result, these receptors are likely to regulate a vasomotor response that is spatially and temporally complex. In addition, the formation of potentially lethal pores during sustained activation of $\mathrm{P}_{2} \mathrm{X}_{7}$ receptors (Surprenant et al. 1996; Sugiyama et al. 2002) raises the possibility that these purinergic receptors could play a role in various pathological retinopathies in which pericytecontaining microvessels are damaged (Cogan et al. 1961).

\section{REFERENCES}

Anderson D R (1996). Glaucoma, capillaries and pericytes. 1. Blood flow regulation. Ophthalmologica 210, 257-262.

Barry P H (1994). JPCalc, a software package for calculating liquid junction potential corrections in patch-clamp, intracellular, epithelial and bilayer measurements and for correcting junction potential measurements. J Neurosci Methods 51, 107-116.

Biedermann B, Frohlich E, Grosche J, Wagner H J \& Reichenbach A (1995). Mammalian Muller (glial) cells express functional D2 dopamine receptors. Neuroreport 6, 609-612.

Boarder M R \& Hourani S M (1998). The regulation of vascular function by $\mathrm{P} 2$ receptors: multiple sites and multiple receptors. Trends Pharmacol Sci 19, 99-107.

Bodin P, Bailey D \& Burnstock G (1991). Increased flow-induced ATP release from isolated vascular endothelial cells but not smooth muscle cells. Br J Pharmacol 103, 1203-1205.

Burnstock G (1990). Dual control of local blood flow by purines. Ann N Y Acad Sci 603, 31-44.

Cario-Toumaniantz C, Loirand G, Ladoux A. \& Pacaud P (1998). $\mathrm{P} 2 \mathrm{X}_{7}$ receptor activation-induced contraction and lysis in human saphenous vein smooth muscle. Circ Res 83, 196-203.

Cogan D, Toussaint D \& Kuwabara T (1961). Retinal vascular patterns. IV. Diabetic retinopathy. Arch Ophthalmol 166, 366-378.

Cotrina M L, Lin J H, Lopez-Garcia J C, Naus C C \& Nedergaard M (2000). ATP-mediated glia signaling. J Neurosci 20, 2835-2844.

Dietrich H H, Ellsworth M L, Sprague R S \& Dacey R G Jr (2000). Red blood cell regulation of microvascular tone through adenosine triphosphate. Am J Physiol Heart Circ Physiol 278, H1294-1298.

Funk R H (1997). Blood supply of the retina. Ophthalmic Res 29, 320-325.

Grynkiewicz G, Poenie M \& Tsien R Y (1985). A new generation of $\mathrm{Ca}^{2+}$ indicators with greatly improved fluorescence properties. J Biol Chem 260, 3440-3450.

Hansen A J, Lund-Andersen H \& Crone C (1977). $\mathrm{K}^{+}$-permeability of the blood-brain barrier, investigated by aid of a $\mathrm{K}^{+}$-sensitive microelectrode. Acta Physiol Scand 101, 438-445. 
Higashi K, Fujita A, Inanobe A, Tanemoto M, Doi K, Kubo T \& Kurachi Y (2001). An inwardly rectifying K(+) channel, Kir4.1, expressed in astrocytes surrounds synapses and blood vessels in brain. Am J Physiol Cell Physiol 281, C922-931.

Kawamura H, Oku H, Li Q, Sakagami K \& Puro D G (2002). Endothelin-induced changes in the physiology of retinal pericytes. Invest Ophthalmol Vis Sci 43, 882-888.

Kuwabara T \& Cogan D (1960). Studies of retinal vascular patterns. 1: normal architecture. Arch Ophthalmol 64, 904-911.

Le Feuvre R, Brough D \& Rothwell N (2002). Extracellular ATP and $\mathrm{P}_{2} \mathrm{X}_{7}$ receptors in neurodegeneration. Eur J Pharmacol 447, 261-269.

Li Q \& Puro D G (2001). Adenosine activates ATP-sensitive K(+) currents in pericytes of rat retinal microvessels: role of A1 and A2a receptors. Brain Res $\mathbf{9 0 7}$, 93-99.

Li Q \& Puro D G (2002). Diabetes-induced dysfunction of the glutamate transporter in retinal Muller cells. Invest Ophthalmol Vis Sci 43, 3109-3116.

Li Y, Holtzclaw L A \& Russell J T (2001). Muller cell Ca ${ }^{2+}$ waves evoked by purinergic receptor agonists in slices of rat retina. $J$ Neurophysiol 85, 986-994.

Lindau M \& Neher E (1988). Patch-clamp techniques for timeresolved capacitance measurements in single cells. Pflugers Arch 411, 137-146.

Murgia M, Hanau S, Pizzo P, Rippa M \& Di Virgilio F (1993). Oxidized ATP. An irreversible inhibitor of the macrophage purinergic P2Z receptor. J Biol Chem 268, 8199-8203.

Nehls V \& Drenckhahn D (1991). Heterogeneity of microvascular pericytes for smooth muscle type alpha-actin. J Cell Biol 113, 147-154.

Newman E A (2001). Propagation of intercellular calcium waves in retinal astrocytes and Muller cells. J Neurosci 21, 2215-2223.

Newman E A (2003). Glial cell inhibition of neurons by release of ATP. J Neurosci 23, 1659-1666.

North R A (2002). Molecular physiology of P2X receptors. Physiol Rev 82, 1013-1067.

North R A \& Surprenant A (2000). Pharmacology of cloned P2X receptors. Annu Rev Pharmacol Toxicol 40, 563-580.

Oku H, Kodama T, Sakagami K \& Puro D G (2001). Diabetesinduced disruption of gap junction pathways within the retinal microvasculature. Invest Ophthalmol Vis Sci 42, 1915-1920.

Pannarale L, Onori P, Ripani M \& Gaudio E (1996). Precapillary patterns and perivascular cells in the retinal microvasculature. A scanning electron microscope study. J Anat 188, 693-703.

Paulson O B \& Newman E A (1987). Does the release of potassium from astrocyte endfeet regulate cerebral blood flow? Science 237, 896-898.

Postma FR, Hengeveld T, Alblas J, Giepmans BnG, Zondag GCM, Jalink K \& Moolenaar WH (1998). Acute loss of cell-cell communication caused by $\mathrm{G}$ protein-coupled receptors: a critical role for c-src. J Cell Biol 140, 1199-1209.

Puro D G (2002). Diabetes-induced dysfunction of retinal Muller cells. Trans Am Ophthalmol Soc 100, 339-352.

Puro D G \& Stuenkel E L (1995). Thrombin-induced inhibition of potassium currents in human retinal glial (Muller) cells. J Physiol 485, 337-348.

Queiroz G, Gebicke-Haerter P J, Schobert A, Starke K \& von Kugelgen I (1997). Release of ATP from cultured rat astrocytes elicited by glutamate receptor activation. Neuroscience $\mathbf{7 8}$, 1203-1208.

Ramirez A N \& Kunze D L (2002). P2X purinergic receptor channel expression and function in bovine aortic endothelium. Am J Physiol Heart Circ Physiol 282, H2106-2116.
Sakagami K, Kodama T \& Puro D G (2001). PDGF-induced coupling of function with metabolism in microvascular pericytes of the retina. Invest Ophthalmol Vis Sci 42, 1939-1944.

Sakagami K, Wu D M \& Puro D G (1999). Physiology of rat retinal pericytes: modulation of ion channel activity by serum-derived molecules. J Physiol 521, 637-650.

Schonfelder U, Hofer A, Paul M \& Funk R H (1998). In situ observation of living pericytes in rat retinal capillaries. Microvasc Res 56, 22-29.

Schwartz E A (1993). L-glutamate conditionally modulates the $\mathrm{K}^{+}$ current of Muller glial cells. Neuron 10, 1141-1149.

Shepro D \& Morel N M (1993). Pericyte physiology. FASEB J 7, 1031-1038.

Sugiyama T, Kawamura H \& Puro D G (2002). Activation of P2X receptors as a death signal in the normal and diabetic retinal microvasculature. Invest Ophthalmol Vis Sci 43, E-1340.

Surprenant A, Rassendren F, Kawashima E, North R A \& Buell G (1996). The cytolytic P2Z receptor for extracellular ATP identified as a $\mathrm{P} 2 \mathrm{X}$ receptor $\left(\mathrm{P} 2 \mathrm{X}_{7}\right)$. Science $272,735-738$.

Tilton R G (1991). Capillary pericytes: perspectives and future trends. J Electron Microsc Tech 19, 327-344.

von Albertini M, Palmetshofer A, Kaczmarek E, Koziak K, Stroka D, Grey S T, Stuhlmeier K M \& Robson S C (1998). Extracellular ATP and ADP activate transcription factor NF-kappa B and induce endothelial cell apoptosis. Biochem Biophys Res Commun 248, 822-829.

von Kugelgen I \& Wetter A (2000). Molecular pharmacology of P2Yreceptors. Naunyn Schmiedebergs Arch Pharmacol 362, 310-323.

Wagner U \& Wiederholt M (1996). Membrane voltage and wholecell currents in cultured pericytes of control rats and rats with retinal dystrophy. Curr Eye Res 15, 1045-1053.

Wang Z, Haydon P G \& Yeung E S (2000). Direct observation of calcium-independent intercellular ATP signaling in astrocytes. Anal Chem 72, 2001-2007.

Wu D M, Kawamura H, Li Q \& Puro D G (2001). Dopamine activates ATP-sensitive $\mathrm{K}^{+}$currents in rat retinal pericytes. Vis Neurosci 18, 935-940.

Wu D M, Kawamura H, Sakagami K, Kobayashi M \& Puro D G (2003). Cholinergic regulation of pericyte-containing retinal microvessels. Am J Physiol Heart Circ Physiol 284, H2083-2090.

Ye X D, Laties A M \& Stone R A (1990). Peptidergic innervation of the retinal vasculature and optic nerve head. Invest Ophthalmol Vis Sci 31, 1731-1737.

\section{Acknowledgements}

The authors thank Bret Hughes for helpful discussions and generously allowing the authors the use of equipment. This work was supported by grants from the NIH, EY12505 and EY07003. D.M.W. received a Physician-Scientist Training Award from the American Diabetes Association and a Research to Prevent Blindness Medical Student Research Fellowship. D.G.P. is a Harrington Research to Prevent Blindness Senior Scientific Scholar.

\section{Supplementary material}

The online version of this paper can be found at:

$$
\text { DOI: 10.1113/jphysiol.2003.047977 }
$$

and contains material entitled:

Time-lapse movie showing BzATP-induced contraction of a pericyte-containing microvessel. 